\title{
Bacterial contamination levels in river catchments of the North West Province, South Africa: Public health implications
}

\author{
Constance Wose Kinge ${ }^{1 \star}$ and Moses Mbewe $^{2}$ \\ ${ }^{1}$ School of Environmental and Health Sciences, North-West University, Mafikeng Campus Private Bag X2046, \\ Mmabatho 2735, South Africa. \\ ${ }^{2}$ School of Agricultural and Environmental Sciences, University of Limpopo, Turflop Campus, P. Bag 1107, \\ Sovenga 0727, South Africa.
}

Accepted 16 December, 2011

\begin{abstract}
The aim of this study was to examine and compare the levels of bacterial contamination in water obtained from the five river catchments in the North West Province with water quality guidelines. A total of 54 water samples collected during winter and summer seasons were cultured on $\mathrm{m}$-FC and $\mathrm{m}$-Endo agar plates using membrane filtration, and on Plate Count and Eosin Methylene Blue agar plates using spread-plate techniques. Biochemical characterisation of suspected Escherichia coli and Klebsiella isolates by Triple Sugar Iron (TSI) and serotyping using E. coli poly D1-D8 and Klebsiella capsular Types 1-6 antisera were performed for confirmatory identification. Results showed significantly high levels of contamination when using heterotrophic, total and faecal coliform counts as an indicator in all catchments in summer and winter seasons. In winter season, E. coli and Klebsiella were maximal in the Marico and Molopo catchment with 75 and $95 \%$ prevalence, respectively. The Crocodile and Elands and Marico and Hex catchments during summer also showed high levels of E. coli $(63 \%)$ and Klebsiella (76\%) contamination, respectively. Contamination levels were widespread and above the South African Department of Water Affairs' guidelines for domestic, recreational and irrigation water were used. The consumption of such untreated water sources directly or indirectly, poses a health risk to consumers. Strict measures to ensure the discharge of properly treated effluent into the rivers should be put in place, to minimise the spread of potential pathogenic bacteria and the occurrence of water borne disease outbreaks.
\end{abstract}

Key words: River catchments, heterotrophic bacteria, total coliforms, faecal coliforms, Escherichia coli, Klebsiella, serotyping.

\section{INTRODUCTION}

Rivers and streams are valuable freshwater resources that provide important habitats for nature conservation, recreation, transportation and economic growth. Due to the scarcity of water in South Africa, extensive exploitation of water resources such as dams, pools, unprotected rivers and springs for domestic and other water uses, is

${ }^{*}$ Corresponding author. E-mail: conskinge@yahoo.ca. Tel: +27 (0) 18389 2134. Fax: +27 (0) 183892134. common, particularly in the rural communities where access to potable water supply is limited (Younes and Bartram, 2001). Despite the important role that rivers and their catchments play to socio-economic growth, most rivers are no longer in their natural state because human activities have resulted in pollution of these water bodies (Wetzel, 2001). This places the human population at high risk of contracting water-related diseases like typhoid, cholera, bacterial and amoebic dysentery, enteritis, poliomyelitis, infectious hepatitis, schistosomiasis and gastroenteritis (Mallon and Corkill, 2002; Obi et al., 
2002).

The North West Province of South Africa is a principally dry province with surface, ground, imported water and reuseable effluent being the province's four major water sources together with a few rivers that are used by the rural population (SER, 2002). Within its provincial boundaries are four water management areas, which manage five river catchments in the province. The five catchments include the Crocodile and Elands, Marico and Hex, Marico and Molopo, Mooi and Vaal, and the Harts (SER, 2002).

The major rivers in these catchments include: Crocodile, Elands, Hex, Groot Marico, Molopo, Mooi, Skoonspruit and Vaal, as well as the Marico Bosveld, Molatedi, Boskop, Vaalkop, Hartebeesport, Rooikopjes, Potchefstroom, Bloemhof, and Modimola Dams (DWA, 2007). Crop, livestock, chicken and even crocodile farming, irrigation, informal settlements, and mining are seen as the main human activities in these river catchments (DWA, 2007). These activities independently or in combination, contribute to heavy discharges into the rivers with significant impacts on the water quality in these catchment areas (DWA, 2007).

Major water quality problems encountered in South Africa include over-utilisation of riparian zones in rivers, water shortage where the demand for water exceeds its accessibility (Elmanama et al., 2005). The degree of river water pollution varies according to the quantity and quality of the pollutant. Pollution presents a major health risk for recreational and domestic use of water (Elmanama et al., 2005). Contamination of soil and surface waters with faecal material enhances the risk of human exposure to pathogenic enteric bacteria of intestinal origin (Shehane et al., 2005). According to Midgley et al. (1994 a, b, c), the major pollutants in these catchment areas include treated and untreated domestic sewage, industrial and mining effluents, agricultural return flows and storm water run-offs from urban surfaces.

The high levels of microbial contamination that South African water resources receive are due to a lack of proper sanitation facilities especially in the rural areas, and the fact that no published data exist on the bacterial quality of rivers in the North West province, makes routine detection of pathogenic enteric bacteria in environmental samples of major concern of any public health strategy (Moganedi et al., 2007). The aim of this study therefore was to use indicator bacteria (heterotrophic bacteria, total and faecal coliforms, as well as E. coli and Klebsiella spp.) to assess the contamination levels and confirm the presence of contamination in river catchments of the province and to compare the results with standard water quality guideline values.

\section{MATERIALS AND METHODS}

A total of 54 water samples were collected in the winter (April, 2007 to August, 2007) and summer (November, 2007 to March, 2008) seasons from the major rivers of the Crocodile and Elands, Marico and Hex, Marico and Molopo, Mooi and Vaal, and Harts River catchments of the North West Province. Five hundred milliliters $(500 \mathrm{ml})$ of water samples were collected downstream, midstream and upstream in clean sterile $500 \mathrm{ml}$ Schott Duran bottles. Samples were transported on ice to the laboratory for analysis. Upon arrival, all samples collected were plated out within $24 \mathrm{~h}$.

\section{Enumeration of heterotrophic bacteria}

Analyses of water samples were performed using the spread-plate method (Standing Committee of Analysts, 2002). In brief, $1 \mathrm{ml}$ of each water sample was enriched in $9 \mathrm{ml}$ of $2 \%$ Buffered peptone (Biolab, Merck Diagnostics, South Africa) and serial dilutions performed. Aliquots of $0.1 \mathrm{ml}$ of each dilution were plated out on plate count agar (PCA) (Biolab, Merck Diagnostics, South Africa) in duplicates. All plates were incubated at $37^{\circ} \mathrm{C}$ for $24 \mathrm{~h}$. All colonies were counted and the results recorded as $\mathrm{cfu} / \mathrm{ml}$.

\section{Enumeration of total and faecal coliform bacteria}

Analyses of water samples for total and faecal coliform bacteria were performed using membrane filtration method (APHA, 1998). Briefly, $100 \mathrm{ml}$ of each water sample was filtered through $0.4 \mu \mathrm{m}$ grid filter units (Type $\mathrm{AH}$ ) using a Gelman little giant pressure/vacuum pump machine model 13156-Gelman Sciences, Michigan USA. Membrane filters with retained bacteria were placed on m-Endo agar (Biolab, Merck Diagnostics, South Africa) and mFC agar (Biolab, Merck Diagnostics, South Africa) plates in triplicates for the enumeration of total and faecal coliforms, respectively. All m-Endo plates were incubated at $37^{\circ} \mathrm{C}$ for $24 \mathrm{~h}$ while $\mathrm{m}-\mathrm{FC}$ plates were incubated at $44.5^{\circ} \mathrm{C}$ for $24 \mathrm{~h}$ (Anon, 2000; Rompré et al., 2002). Characteristic metallic shine and blue coloured colonies on m-Endo and m-FC agar plates, respectively, were counted and the results recorded as cfu/100 ml of water.

\section{Isolation of E. coli and Klebsiella spp.}

Water analysis for E. coli and Klebsiella isolation was done using the spread plate method on Eosin Methylene Blue (EMB) agar (Biolab, Merck Diagnostics, South Africa). In brief, $1 \mathrm{ml}$ of each water sample was diluted in $9 \mathrm{ml}$ of $2 \%$ buffered-peptone water and serially diluted. Aliquots of each dilution $(0.1 \mathrm{ml})$ were plated and all plates were incubated at $37^{\circ} \mathrm{C}$ for $24 \mathrm{~h}$. Suspect $E$. coli and Klebsiella isolates on EMB agar plates were sub-cultured on fresh media. Plates were incubated at $37^{\circ} \mathrm{C}$ for $24 \mathrm{~h}$. The isolates were then preserved on 2.3\% w/v Nutrient agar (Biolab, Merck Diagnostics, South Africa) plates for further analysis.

\section{Biochemical characteristics of E. coli and Klebsiella spp.}

Based on their colonial morphology on EMB agar and Gram coloration, all suspected E. coli and Klebsiella isolates were subjected to Triple Sugar Iron (TSI) agar (Biolab, Merck Diagnostics, South Africa) test for preliminary identification as coliforms (Prescott, 2002). The isolates were streak-plated on TSI agar slopes prepared in sterile $15 \mathrm{ml} \mathrm{McCartney} \mathrm{bottles.} \mathrm{Following}$ inoculation, the bottles were incubated at $37^{\circ} \mathrm{C}$ for $24 \mathrm{~h}$.

\section{Serological analysis}

Isolates presumptively confirmed as E. coli and Klebsiella spp. by 
biochemical tests were subjected to serotyping by slide agglutination tests with $E$. coli poly D1-D8 and Klebsiella capsular Types 1-6 antisera (Davies Diagnostics, South Africa) according to manufacturer's instructions. Briefly, two $10 \mu \mathrm{l}$ volumes of sterile $0.85 \%$ saline solution were placed on sterile microscope slides. A single pure colony of isolate was picked with sterile toothpicks and emulsified on both drops to obtain a distinct and uniform turbidity. Aliquots of each polyvalent antiserum $(10 \mu \mathrm{l})$ were added to one of the emulsions and a drop of saline was added to the other emulsion as a control. After $60 \mathrm{~s}$ of gentle rocking, the slides were observed for the formation of a precipitate on the test sample.

\section{Statistical analyses}

All bacterial counts obtained were analysed using the student's ttest to compare the contamination levels between the two seasons. Probability was set at $\mathrm{p}=0.05$.

\section{RESULTS}

Table 1 shows the mean bacterial contamination levels for both winter and summer seasons.

\section{Bacterial contamination levels in winter}

The total culturable heterotrophic bacteria in all catchment areas were above the South African permissible levels prescribed by the Department of Water Affairs in water meant for domestic use $(100 \mathrm{cfu} / \mathrm{ml})$ in all catchments (DWA, 1996) as shown in Table 1. In addition, total heterotrophic bacterial counts were more than the permissible $10000 \mathrm{cfu} / \mathrm{ml}$ for agricultural water use (DWA, 1998) in the Crocodile and Elands, and the Mooi and Vaal catchment, which was significantly higher $(p=0.045)$. Similarly, total coliform bacterial levels obtained in all catchment areas in the winter season exceeded the South African permissible levels of 10 $\mathrm{cfu} / 100 \mathrm{ml}$ (DWA, 1996) in water meant for domestic use. The levels of faecal coliform bacterial contamination obtained in all river catchment areas were higher than the South African and international minimum permissible levels of $0 \mathrm{cfu} / 100 \mathrm{ml}$ for water meant for domestic and recreational use (DWA, 1996, 1998; WHO, 2004).

\section{Bacterial contamination levels in summer}

Heterotrophic bacterial counts obtained in summer season were higher when compared to the levels obtained in the winter season. The total heterotrophic bacterial counts in all five catchments were above permissible levels prescribed for drinking (100 cfu/ml) water use. Similarly, total coliform bacteria were isolated in all catchment areas and the contamination levels were greater than the permissible $10 \mathrm{cfu} / 100 \mathrm{ml}$ for domestic water use. Values obtained showed high significance in the Marico and $\operatorname{Hex}(p=0.042)$, Marico and Molopo $(\mathrm{p}=0.016)$, and Harts $(\mathrm{p}=0.011)$ catchments. Furthermore, results of faecal bacterial contamination levels exceeded the permissible $0 \mathrm{cfu} / 100 \mathrm{ml}$ level for water meant for drinking and recreational purposes in all catchment areas with significantly high $(p=0.005)$ levels in the Marico and Molopo catchment area.

\section{Biochemical and serological analysis}

The Agglutination test was used as a confirmatory identification test and results obtained showed that $E$. coli and Klebsiella species were isolated from all catchment areas. The percentages of E. coli and Klebsiella isolates obtained, showing a positive agglutination to antisera, were calculated for each catchment area and results recorded as contained in Tables 2 and 3 . The prevalence of Klebsiella species in winter and summer seasons was between 37 to $94 \%$, and 6 to $63 \%$, respectively as depicted in Table 2. Similarly, Table 3 shows a 24 to $75 \%$ and 25 to $76 \%$ prevalence of $E$. coli (the main indicator for faecal contamination) in winter and summer, respectively. In winter season, E. coli and Klebsiella were maximal in the Marico and Molopo catchment with 75 and 95\% prevalence, respectively. The Crocodile and Elands and Marico and Hex catchments during summer also showed high levels of E. coli (63\%) and Klebsiella (76\%) contamination, respectively.

\section{DISCUSSION}

Heterotrophic bacteria are generally used as a monitoring tool to assess the efficiency of water treatment and disinfection processes (Pavlov et al., 2004). The high levels of heterotrophic bacterial contamination observed in all catchments, particularly in the Mooi and Vaal catchment, which was significantly high in the winter season, may suggest inefficiency in the Orkney and Bloemhof wastewater treatment plants located in the catchment area. The levels of contamination present in all catchments exceeded the maximum safety limits. This is in agreement with other findings reported by Nevondo and Cloete (1999), Bezuidenhout et al. (2002), Obi et al. (2002, 2004), Germs et al. (2004).

The presence of such high levels of heterotrophic bacterial contamination may pose increasingly high risk of infection to consumers with opportunistic bacteria such as Klebsiella, Aeromonas and Psuedomonas, which have been implicated in diarrhoea and other water borne diseases (El-Sheikh and El-Assouli, 2001; Bartram et al., 2003). For agricultural water used for irrigation, the levels of heterotrophic bacterial contamination in the Crocodile and Elands, Mooi and Vaal catchments were higher than the permitted $10000 \mathrm{cfu} / \mathrm{ml}$ levels (DWA, 1996). However, contamination levels were within limits for the Marico and Hex, Marico and Molopo and Harts catchments. 
Table 1. Mean bacterial contamination levels in river catchments for both summer and winter seasons.

\begin{tabular}{lcc|cc|c|c}
\hline \multirow{2}{*}{ River catchments } & \multicolumn{2}{c|}{ Heterotrophic bacterial counts (cfu/ml) } & \multicolumn{2}{|c|}{ Total coliform counts (cfu/100 ml) } & Faecal coliform counts (cfu/100 ml) \\
\cline { 2 - 7 } & Winter & Summer & Winter & Summer & Winter & Summer \\
\hline Crocodile and Elands & $4.9 \times 10^{5}$ & $2.7 \times 10^{4}$ & $7.0 \times 10^{1}$ & $1.1 \times 10^{2}$ & $1.1 \times 10^{1}$ \\
Marico and Hex & $5.3 \times 10^{3}$ & $1.0 \times 10^{5}$ & $5.3 \times 10^{1}$ & $1.3 \times 10^{2 a}$ & $5.7 \times 10^{1}$ \\
Marico and Molopo & $3.5 \times 10^{4}$ & $1.4 \times 10^{3}$ & $4.4 \times 10^{1}$ & $1.4 \times 10^{2 a}$ & $1.8 \times 10^{1}$ & $6.7 \times 10^{1}$ \\
Mooi and Vaal & $5.0 \times 10^{5 a}$ & $1.7 \times 10^{4 b}$ & $8.5 \times 10^{1}$ & $9.2 \times 10^{1}$ & $9.3 \times 10^{1 a}$ & $2.2 \times 10^{1}$ \\
Harts & $2.3 \times 10^{4}$ & $4.0 \times 10^{4}$ & $3.5 \times 10^{1}$ & $1.7 \times 10^{2 a}$ & 8 \\
\hline
\end{tabular}

a $=$ bacterial counts were significantly high $(p<0.05)$ between seasons, ${ }^{b}=$ bacterial counts were significantly high $(P<0.05)$ between catchments.

Table 2. Biochemical characteristics of Klebsiella spp. isolated from river catchments.

\begin{tabular}{|c|c|c|c|c|c|c|c|c|c|}
\hline \multirow{2}{*}{ River catchments } & \multirow{2}{*}{ No. of isolates identified } & \multirow{2}{*}{ Motility } & \multicolumn{5}{|c|}{ TSI } & \multicolumn{2}{|c|}{$\%$ of Klebsiella spp. } \\
\hline & & & $\mathbf{G}$ & $\mathrm{S}$ & $\mathbf{L}$ & $\mathrm{H}_{2} \mathrm{~S}$ & Gas & Winter & Summer \\
\hline Crocodile and Elands & 8 & - & + & + & + & - & + & 37 & 63 \\
\hline Marico and Molopo & 66 & - & + & + & + & - & + & 94 & 6 \\
\hline Marico and Hex & 22 & - & + & + & + & - & + & 68 & 32 \\
\hline Mooi and Vaal & 36 & - & + & + & + & - & + & 86 & 14 \\
\hline Harts & 26 & - & + & + & + & - & + & 50 & 50 \\
\hline
\end{tabular}

TSI= Triple Sugar Iron, $\mathrm{G}=$ glucose, $\mathrm{S}=$ sucrose, $\mathrm{L}=$ lactose, $\mathrm{H}_{2} \mathrm{~S}=$ Hydrogen sulphide, $+=$ positive, $-=$ negative.

Table 3. Biochemical characteristics of $E$. coli isolated from river catchments.

\begin{tabular}{|c|c|c|c|c|c|c|c|c|c|}
\hline \multirow{2}{*}{ River catchment } & \multirow{2}{*}{ No of isolates identified } & \multirow{2}{*}{ Motility } & \multicolumn{5}{|c|}{ TSI } & \multicolumn{2}{|c|}{$\%$ of E. coli } \\
\hline & & & $\mathbf{G}$ & $\mathbf{S}$ & $\mathbf{L}$ & $\mathrm{H}_{2} \mathrm{~S}$ & Gas & Winter & Summer \\
\hline Crocodile and Elands & 71 & + & + & + & + & - & - & 55 & 45 \\
\hline Marico and Molopo & 85 & + & + & + & + & - & - & 75 & 25 \\
\hline Marico and Hex & 34 & + & + & + & + & - & - & 24 & 76 \\
\hline Mooi and Vaal & 66 & + & + & + & + & - & - & 35 & 65 \\
\hline Harts & 9 & + & + & + & + & - & - & 45 & 55 \\
\hline
\end{tabular}

TSI= Triple Sugar Iron, $\mathrm{G}=$ glucose, $\mathrm{S}=$ sucrose, $\mathrm{L}=$ lactose, $\mathrm{H}_{2} \mathrm{~S}=\mathrm{Hydrogen}$ sulphide, $+=$ positive, - = negative.

Total coliform bacteria comprise those of faecal and non-faecal origin. Their presence in any body of water is a general indication of the hygienic quality, confirmed by the presence of potential pathogenic bacteria including Salmonella, Shigella, Vibrio cholerae and E. coli species (Neill,
2004; Zamxaka et al., 2004). Counts of these bacteria are primarily used to assess the operational efficiency of water treatment 
processes and microbial growth in a distribution system or post-treatment contamination of drinking water (Pitkänen et al., 2007). The total coliform bacterial contamination obtained during this study were also found to be present in all the catchments and above the permissible levels of $10 \mathrm{cfu} / 100 \mathrm{ml}$ in water meant for domestic use (DWA, 1999), with significantly high levels in the Marico and Hex, Marico and Molopo and Harts catchments during the summer season. Such high levels are also an indication of inadequate water treatment processes with poor water quality that could result in significant disease-transmission rates such as gastroenteritis, salmonellosis, dysentery, cholera and typhoid fever (DWA, 1996).

Furthermore, the very high numbers of faecal coliform bacterial contamination observed in all catchments could not be underestimated. Significantly high levels were observed for the Marico and Molopo catchment in summer. According to $\mathrm{WHO}$ and DWA standards, no faecal coliform bacteria should be detected in any given body of water intended for domestic and recreational use. In full contact recreational waters, faecal coliform counts between 0 and $130 \mathrm{cfu} / 100 \mathrm{ml}$ present a potential risk of gastrointestinal effects (DWA, 1999; WHO, 2008). The severity of such health effects increases with increasing number of faecal coliforms present, which is an indication of recent faecal or other contamination, inadequate treatment or post-treatment deficiencies (Zamxaka et al., 2004).

Although, faecal coliform bacterial counts were above limits for domestic and recreational water use, these were within permissible limits in agricultural water used for livestock farming. The permissible counts are between 0 and $200 \mathrm{cfu} / 100 \mathrm{ml}$ for young and mature livestock, swine, poultry and between $10000-50000 \mathrm{cfu} / 100 \mathrm{ml}$ for irrigation (DWA, 1996). Generally, faecal coliform bacteria inhabit the gastrointestinal tract of all warm and some cold-blooded animals as normal commensals. As a result, their presence in water cannot be pinpointed to a specific source of faecal contamination. However, faecal material from human and animal sources can be regarded as high risk due to the possible presence of pathogenic bacteria (Harwood et al., 2000).

The widespread distribution of $E$. coli and Klebsiella, as well as Shigella observed from our previous study (Wose Kinge and Mbewe, 2010), further confirms the presence of faecal contamination in all catchments. These enteric bacteria are reported to be the causative agents of various water and food borne diseases including diarrhoea. The total number of $E$. coli obtained exceeded the permissible level of $0 \mathrm{cfu} / \mathrm{ml}$ in water intended for drinking prescribed by DWA (1996). According to DWA (1996), water meant for irrigation should contain no $E$. coli bacteria. As observed in this study, the total levels of E. coli contamination for both winter and summer seasons do not meet this criterion. The use of such contaminated water for irrigation could result in the transmission of these bacteria to humans through contaminated vegetables and other crops eaten raw, as well as milk from grazing cattle.

The presence of opportunistic pathogens such as Klebsiella species may have serious implications for consumers that utilize water directly or indirectly from the rivers (Genthe and Steyn, 2006). The close proximity of wastewater treatment plants, informal settlements, hospitals, industrial and agricultural processes, and livestock farms to the catchment areas, might have contributed independently or in combination to the high levels of bacterial contamination observed. This is in agreement with the findings of Akoachere et al. (2008).

Rainfall in the five catchment areas of the North West province may be highly variable, often resulting in severe droughts or flooding (N.W. Province-SOTE, 2002). The river system is strongly influenced by the rainfall during the summer season with an average annual rainfall ranging from 150 to $700 \mathrm{~mm}$ (N.W. Province-SOTE, 2002). Studies have shown that faecal coliforms, more specifically $E$. coli, increases after a rainfall but thereafter, decrease as a result of the process of sedimentation (Webster et al., 2004; Chigbu et al., 2005; Elmanama et al., 2005). The levels of bacterial contamination in all the five river catchments were widespread during winter and summer seasons. It is possible that the rainfall events in all five catchment areas could negatively impact on the water quality of the rivers in these catchments.

The presence of indicator bacteria like $E$. coli, Klebsiella, and Shigella is a clear-cut indication of faecal contamination in the catchment areas. As a result, water from these catchments is not suitable for domestic and recreational use as it is before treatment. Although the water may be good for livestock farming, water from the Marico and Molopo, Marico and Hex, and Harts catchments is not suitable for irrigational use. The use of such contaminated water for irrigation would result in the transmission of potential pathogenic bacteria to humans through contaminated vegetables and other crops eaten raw, as well as milk from grazing cattle. River water sources in the North West Province therefore, should be regarded as possible pathways for human contamination during recreational and domestic activities. Water management authorities may want to consider the findings of this study as an additional aid to assist and better manage water resources in and around the province, monitor sources of pollution in these catchment areas, and ensure the proper discharge of untreated sewage and industrial effluents into water bodies, in view to maintaining good water quality.

\section{ACKNOWLEDGEMENTS}

We wish to thank Beleng J. and Njemla T., in the School of Agricultural Sciences for the assistance with sample collection, and also the North-West University for 
financial aid.

\section{REFERENCES}

Akoachere J-F, Oben PM, Mbivnjo BS, Ndip LM, Nkwelang G, Ndip RN (2008). Bacterial indicators of pollution of the Douala lagoon, Cameroon: public health implications. Afr. Health Sci., 8(2): 85-89.

Anon (2000). Rural water sources under the microscope. SA Water Bull., 26(3): 18-21.

APHA (1998). Standard methods for the examination of Water and Wastewater. American Public Health Association $\left(19^{\text {th }}\right.$ edn) Washington DC, pp. 946.

Bartram J, Cotruvo J, Exner M, Fricker C, Glasmacher A (2003). Heterotrophic plate counts in drinking water safety. World Health Organ. X, 1-256.

Bezuidenhout CC, Mthembu N, Puckree T, Lin J (2002). Microbiological evaluation of the Mhlathuze River, KwaZulu Natal (RSA). Water SA. 28(93): 281-286

Chigbu P, Gordon S, Strange TR (2005). Feacal coliform bacteria disappearance rates in a north-central Gulf of Mexico estuary. Estuarine, Coastal Shell Sci., 65: 309 -318.

DWA (2007). Integrated Vaal River system WMR studies. Department of Water Affairs, Pretoria.

DWA (1999). Geohydrological Data Access System-The Water Management Area of South Africa. Department of Water Affairs.

DWA (1998). Quality of Domestic Water Supplies: Assessment Guide, pp. 1.

DWA (1996). South Africa Water Quality Guidelines $\left(2^{\text {nd }}\right.$ edn) volume 1: Domestic use and volume 2: Agricultural water use. Irrigation, pp. 190.

Elmanama AA, Afifi S, Bahr S (2005). Seasonal and spatial variation in the monitoring parameters of Gaza beach during 2002-2003. Environ. Res., pp. 1-9.

El-Sheikh SM, El-Assouli SM (2001). Prevalence of viral bacterial and parasitic enteropathogens among young children with acute diarrhoea in Jeddah, Saudi Arabia. J. Health Pop. Nutr., 19(1): 25-30.

Genthe B, Steyn M (2006). Good intersectoral water governance- a Southern African decision-makers guide. Chapter on Health and Water. CSIR/NRE/WR/EXP/2006/0047/A.

Germs W, Coetzee MS, VAN Rensburg L, Maboeta MS (2004). Short Communication: A preliminary assessment of the chemical and microbial water quality of the Chunies River-Limpopo. Water SA., 30(2): ISSN 0378-4738.

Harwood VJ, Whitlock J, Withington V (2000). Classification of antibiotic resistance patterns of indicator bacteria by discriminant analysis: use in predicting the sources of faecal contamination in subtropical waters. Appl. Environ. Microbiol., 66(9): 3698-3704.

Mallon L, Corkill K (2002). Excretion of vancomycin resistant enterococci by wild mammals. J. Emerg. Infect. Dis., 8(6): 637-638.

Midgley DC, Pitman WV, Middleton BJ (1994a). Surface water resources of South Africa, volume 1, Appendices. WRC Report No. 298/1.1/94. WRC, Pretoria.

Midgley DC, Pitman WV, Middleton BJ (1994b). Surface water resources of South Africa, volume II, Appendices. WRC Report No. 298/2.1/94. WRC, Pretoria.

Midgley DC, Pitman WV, Middleton BJ (1994c). Surface water resources of South Africa, volume III, Appendices. WRC Report No. 298/3.1/94. WRC, Pretoria.

Moganedi KLM, Goyvaerts EMA, Venter SN, Sibara MM (2007). Optimisation of the PCR-invA primers for the detection of Salmonella in drinking and surface waters following a pre-cultivative step. Water SA., 33(2): 195-201.
Neill M (2004). Microbiological indices for total coliforms and E. coli bacteria in estuarine waters. Marine Pol. Bull., 49: 752-760.

Nevondo TS, Cloete TE (1999). Bacterial and chemical quality of water supply in the Dertig village settlement. Water SA., 25(2): 215-220.

N.W. PROVINCE-SOTE (2002). North-West Province State of the Environment Report. (available at: http:www.enviroiiment.gov.zdsoer!reports!northwest!01\%20Contents. pdf).

Obi CL, Bessong PO, Momba MNB, Potgieter N, Samie A, Igumbor EO (2004). Profiles of antibiotic susceptibilities of bacterial isolates and physico-chemical quality of water supply in rural Venda communities, South Africa. Water SA, 30(4): 515-520.

Obi CL, Potgieter N, Bessong PO, Matsaung G (2002). Assessment of the microbial quality of river water sources in rural Venda communities in South Africa. Water SA, 28(3): 287-292.

Pavlov D, De Wet CME, Grabow WOK, Ehlers MM (2004). Potentially pathogenic features of heterotrophic plate count bacteria isolated from treated and untreated drinking water. Int. J. Food Microbiol. 92 275-287.

Pitkänen T, Paakkari P, Miettinen IT, Heinonen-Tanski H, Paulin L, Hänninen M (2007). Comparison of media for enumeration of coliform bacteria and Escherichia coli in non-disinfected water. J. Microbiol. Methods, 68: 522-529.

Prescott H (2002). Laboratory exercise in Microbiology. Smith publishers, New York. $5^{\text {th }}$ Ed, pp. 133.

Rompré A, Servais P, Baudart J, De-Roubin MR, Laurent P (2002). Detection and enumeration of coliforms in drinking water: current methods and emerging approaches. J. Microbiol. Methods, 49: 31-34.

SER (2002). State of Emergency Report, North West Province, South Africa.

Shehane SD, Harwood VJ, Whitlock JE, Rose JB (2005). The influence of rainfall on the incidence of microbial feacal indicators and the dominant sources of feacal pollution in a Florida river. J. Appl. Microbiol., 98(5): 1 127-1 136.

Standing Committee of Analysts (2002). The microbiology of drinking water 2002 -Part 7 - The enumeration of heterotrophic bacteria by pour and spread plate techniques. Methods for the Examination of Waters and Associated Materials, Environment Agency, London.

Webster LF, Thompsona BC, Fultona MH, Chestnut DE, Van Dolah RF, Leight AK, SCOTT GI (2004). Identification of sources of Escherichia coli in South Carolina estuaries using antibiotic resistance analysis. J. Exp. Marine Biol. Ecol., 298: 179-195.

Wetzel RG (2001). Limnology: lake and river ecosystems. ( $3^{\text {rd }}$ edn) Academic Press. San Diego, pp. 1006.

WHO (2004). Guidelines for drinking-water quality, recommendations. Microbiological Methods, vol.1. World Health Organization, Switzerland, Geneva, pp. 515.

WHO (2008). Guidelines for drinking-water quality: incorporating 1st and 2nd addenda, vol.1, Recommendations $-3^{\text {rd }}$ edn, World Health Organization, Switzerland, Geneva, pp. 668

Wose Kinge C, Mbewe M (2010). Characterization of Shigella species isolated from river Catchments in the North West Province of South Africa. S. Afr. J. Sci., 106(11/12): 1-4.

Younes M, Bartram J (2001). Waterborne health risks and the WHO perspectives. Int. J. Hyg. Environ. Health, 204: 255-263.

Zamxaka M, Pironcheva G, Zamxaka NYO (2004). Bacterial Community patterns of domestic water sources in the Gogogo and Nkonkobe areas of the Eastern Cape Province, South Africa. Water SA., 30: $341-346$. 